\title{
Analysis of Highly Fractionated Felsic Systems Associated with Sn- W-Mo Deposits: Examination of Dynamic Thermal Constraints
}

\author{
DAVID R LENTZ ${ }^{1}$ \\ ${ }^{1}$ Department od Earth Sciences, University of New \\ Brunswick, 2 Bailey Drive, Fredericton, NB E3B5A3 \\ Canada,dlentz@unb.ca
}

Granophile mineral deposits with $\mathrm{Sn}, \mathrm{W}$, and Mo, as well as $\mathrm{U}, \mathrm{Li}, \mathrm{Cs}, \mathrm{Ta}$, etc., have long been known to be associated with highly fractionated magmatic systems (Ernst, 2007). The dominant cause involked for fractionation (specialization) has been selective partial melting, crystal fractionation, and (or) fluid fractionation, even preceding magmatic hydrothermal processes that dominate the hydrothermal systems invariably associated with many of these deposit systems. The mechanisms assocated with fractionation have mainly been explored by examining crystal-melt and melt-fluid partitioning equilibria, i.e., bulk $\mathrm{D}$ and $\mathrm{Kd}$ as determined either empirically or experimentally. The mineral-melt $\mathrm{Kd}$ values are generally insenitive to pressure, but the melt-fluid values are highly sensitive to pressure. However, granophile ore deposits are formed in hypabyssal environments, $<2.5 \mathrm{~kb}$ $(250 \mathrm{MPa})$, therefore the processes of ore formation in cupolas are sensitive to pressure. Fractionation aspects have rarely been expored as it relates to the thermal evolution of the crust at either deep to shallow levels. Crystal-melt equilibria with slow cooling is key to enhancing crystal fractionation that can help specialize magmatic systems favoring ore formation associated with magmatic crystallization and magmatic hydrothermal processes. Advective heat transfer in various parts of the crust is easy to model with HEAT 3D, which helps to constrain dynamic thermal models at all scales; these models can then be tested with site specific modelling and then tested geochronologically in regions of interest. This methodology is potentially a predictive tool for examining regions of favorability for exploration, if geological mapping and detailed $\mathrm{U}-\mathrm{Pb}$ geochronology is used in tandem with mineral exploration at any scale.

Ernst, R.E., 2007, Large igneous provinces in Canada through time and their metallogenic potential, in Goodfellow, W.D., ed., Mineral Deposits of Canada: A Synthesis of Major Deposit-Types, District Metallogeny, the Evolution of Geological Provinces, and Exploration Methods: GACMDD, Special Publication No. 5, p. 929-937. 